\title{
RATIONALE OF COLLECTIVE MANAGEMENT ORGANIZATIONS: AN ECONOMIC PERSPECTIVE*
}

\author{
by
}

ZIJIAN ZHANG**

In the market for information goods, externalities occur when the production or consumption of literary and artistic works is not directly reflected in the market. Economic theories regarding the creation of market externalities, the causes for market failures, and the correction of market inefficiencies provide evidence in support of retaining the copyright system as the means of correcting these market failures and inefficiencies and to encourage authorship. This approach can also be adopted to analyze the system of collective management. This article aims at analyzing the rationale of collective management system through an economic approach. The author maintains that collecting societies are effective in dealing with the complicated process of rights management, license granting and remuneration distribution.

\section{KEY WORDS}

Collective Management, Economic Analysis, Externality

\section{INTRODUCTION}

With rapid technological development and substantial reproducing cost reduction, more and more problems concerning copyright protection have raised in recent years. For example, the widespread use of photocopying machines, video and sound recorders could easily copy the original work with highly identical quality. The proliferation of Internet and the subsequent technologies such as peer-to-peer file sharing, made

\footnotetext{
I would like to thank Dr. Wenwei Guan and the anonymous reviewer for their comments on an earlier version of this article. I am also grateful to Jakub Harašta, Radim Polčák, and Jan Zibner in helping me editing this article.

** zjzhang3-c@my.cityu.edu.hk, JSD candidate, School of Law, City University of Hong Kong, China.
} 
the reproduction and dissemination of music available worldwide just within seconds. Facing this increasingly severe piracy issue, diverse industries in copyright are searching for new ways to prevent infringement. These developments have led to a renewed interest in collective forms of exercise of copyright. ${ }^{1}$

It is generally acknowledged that individual exercise of copyright is both difficult - if not feasible - and expensive. ${ }^{2}$ On the one hand, authors find it impossible to negotiate terms with every user who intends to use their works. On the other hand, monitoring costs are prohibitively high. Once they find infringement, the cost of enforcement can be much higher than the royalty that they receive. With large number of users and works involved, individual exercise of copyright cannot cover the costs of original creation, therefore, authors may find creation unmotivated, thus leading to the decrease of works supply. During this process, externality may occur. In economic terms, an externality is the uncompensated impact of one person's actions on the well being of a bystander ${ }^{3}$ (to make an example that is suitable for this contribution, unauthorized reproduction of intellectual goods). Because buyers and sellers neglect the external impact of their own behaviors when deciding how much they would like to supply and demand, the market equilibrium would not be efficient under the situation in which externality exists. ${ }^{4}$ In other words, the social equilibrium does not achieve the benefit-maximizing level as a whole.

The market becomes incapable of allocate resources efficiently when market failure exists. Market power and externalities are particular instances of market failure. ${ }^{5}$ It is suggested that there are three reasons for market failure: (1) externalities, nonmonetizable interest, and noncommercial activities; (2) market barriers (prohibitively high transaction costs); and (3) anti-dissemination motives. ${ }^{6}$ For the purpose of this contribution, I will discuss the first two in the following sections.

\footnotetext{
Hollander, A 1984, "Market Structure and Performance in Intellectual Property: The Case of Copyright Collectives" International Journal of Industrial Organization, vol. 2, pp. 199, 200.

2 Ficsor, M 2002, Collective Management of Copyright and Related Rights, WIPO Publication, 16.

3 Mankiw, NG 2007, Principles of Economics, 4th edn, Cengage Learning Asia Pte, Ltd. 204.

4 Ibid.

5 Id 154.

6 Gordon, WJ 1982, "Fair Use as Market Failure: A Structural and Economic Analysis of the Betamax Case and its Predecessors", Columbia Law Review vol. 82, pp. 1627-35.
} 
Collective management of copyright could be seen as a positive way to deal with copyright licensing. ${ }^{7}$ Under this regime, collective management organizations (CMOs) are societies to which authors of creative works authorize their copyrights. The process of copyright licensing can be described as followed: firstly, potential users of copyrighted works negotiate with CMOs and make an agreement; secondly, users are granted a license and pay the agreed royalties whereas CMOs distribute them to their members after deducting administrative costs; finally, CMOs oversee the use of the works in their repertory and take legal actions where necessary.

Economic literature has long been debating the rationale of CMOs from differing perspectives (e.g. transaction costs, monopoly and competition, and social welfare), especially seeing CMOs as an efficient way of overcoming the problem of high transaction cost for administering copyright in some markets. ${ }^{8}$ For instance, Hollander suggests that the formation of a collective leads to an increase in the number of works being produced. ${ }^{9} \mathrm{He}$ also believes that the statutes of collectives can guarantee the access to the society and the distribution of revenue. ${ }^{10}$ In addition, in a detailed survey performed by Besen, Kirby and Salop, they propose that a closed collective produces fewer than the economically efficient number of songs $^{11}$ whereas efficient negotiation between the monopoly collective and user groups may eliminate any incentive for competitive entry. ${ }^{12}$ When administrative costs are small, they argue that competition among collectives may result. ${ }^{13}$ Besides transaction costs issue, Hansen and Schmidt-Bischoffshausen explore the impact of digital rights management (DRM) on collective management and conclude that DRM can be utilized as a complement of CMOs rather than the end of collective management. ${ }^{14}$

$7 \quad$ Ficsor (N 2) 16.

8 Handke, C \& Towse, R 2007, "Economics of Copyright Collecting Societies", International Review of Intellectual Property and Competition Law, vol. 38, no. 8, pp. 938.

$9 \quad$ Hollander (N 1) 212.

10 Id 213.

11 Besen, SM, Kirby, SN \& Salop, SC 1992, "An Economic Analysis of Copyright Collectives" Virginia Law Review, vol. 78, pp. 394.

12 Id 398.

13 Id 403.

14 Hansen, G \& Schmidt-Bischoffshausen, A 2007, “Economic Funtions of Collecting Societies Collective Rights Management in the light of Transaction Cost - and Information Economics", GRUR Int. vol. 6, pp. 461. 
On the other hand, some commentators also argued that collective management organizations often fail to live up to their potential during rights management, as they share the characteristics of serving their own interests at the expense of artists and the public. ${ }^{15}$ Among the many deficiencies of collective management organizations, corruption and mismanagement are most common seen. For example, such misbehaviors of CMOs can be found in numerous jurisdictions ranged from the most developed countries to economically less developed nations. ${ }^{16}$ Additionally, there is often a time difference between a licensee paying and an artist receiving his money, which is particularly the case in international markets. ${ }^{17}$ Some rights holders also complain that they only receive neglectable royalties as a result of excessive overhead expense and unfair distribution mechanism. ${ }^{18}$ Critique also concentrates upon the blanket licenses offered by CMOs in two aspects:

"(1) the supracompetitive cartel pricing of the blanket license requires broadcasters to devote more time to advertising, which in turn allows less airtime for the performance of songs by lesser-known artists; and (2) the blanket licenses eliminate price competition between songwriters, thereby encouraging broadcasters to play the most popular songs, and royalties to flow to the most popular songwriters." ${ }^{19}$

15 Band, J \& Butler, B 2013, "Some Cautionary Tales about Collective Licensing", Michigan State University College Law International Law Review, vol. 21, pp. 689.

16 Examples include corruption in Brazilian, Spanish, Ghanaian societies, see Gorini, A, "Brazilian Collection Society under Scrutiny",

$<$ http://entertainmentlawbrazil.com.br/2012/05/02/brazilian-collection-society-underscrutiny/>. Enigmax, "Music Rights Groups Raided by Police, Bosses Arrested for Fraud", $<$ https://torrentfreak.com/music-rights-group-raided-by-police-bosses-arrested-for-fraud110702/>. Schultz, MF \& Gelder, AV "Creative Development: Helping Poor Countries by Building Creative Industries",

$<$ http://papers.ssrn.com/sol3/papers.cfm?abstract_id=1338194>.

17 Band \& Butler (N 15) 693.

18 For example, in an article the Canadian professor Michael Geist estimated that the average distribution to authors based on one licensing scheme was \$319. Among its \$33.7 million revenue in 2011, only $\$ 7.8$ million was left to distribute to rights holders. The remaining was allocated to administrative costs, foreign CMOs compensation and ongoing legal battles. Geist, M "The Economics Behind Access Copyright", <http://www.michaelgeist.ca/2011/05/economics-of-access-copyright/>.

19 Reidel, I 2011, "The Taylor Swift Paradox: Superstardom, Excessive Advertising and Blanket Licenses", New York University Journal of Law E Business, vol. 7, pp. 755. 
However, without alternative to the blanket license rights holders have no way to impose market discipline on CMOs by walking away or trying new models. ${ }^{20}$

Despite the fact that CMOs are under various criticisms they still present favorable advantages in rights management, which will be discussed in the article. This article is organized as follows. Section II illustrates that externalities exist in the copyright regime. As a consequence, there is the possibility that users will free ride on copyrighted works. CMOs thus provide copyright holders with enough protection so that they are capable of internalize these negative externalities. Section III deals with transaction costs issue. There are three types of transaction costs (search, bargaining and enforcement costs) that make both the right holders and users overburden while they are dealing with copyright license. It is suggested that CMOs is one of the best solutions that can reduce these costs and facilitate the license process. Section IV claims that in some jurisdictions there is only one $\mathrm{CMO}$ in one particular type of works so monopoly emerges. In order to limit the abuse of monopolistic position by CMOs, governmental intervention is needed. Section V concludes.

\section{COLLECTIVE MANAGEMENT ORGANIZATIONS IN THE FACE OF EXTERNALITIES}

The aim of copyright protection - to incentivize creation and to facilitate the dissemination of knowledge - is somewhat difficult to realize because of the public good aspect of intellectual goods. Thus striking a perfect balance between access to copyrighted works and prevent from unauthorized license has been the pursuit of copyright laws. Before delving into further discussion of externalities, we have to first of all understand authors' incentives of creation with and without a copyright protection from a cost-benefit respect because it is highly relevant to the issue of public goods.

\subsection{WHY AUTHORS CREATE}

An economic analysis of copyright protection shows that copyright laws arise as the result of the fact that the cost of creating a work is high whereas the cost of reproducing it is relatively low. ${ }^{21}$ It is suggested that two costs

${ }^{20}$ Band \& Butler (N 15) 704.

${ }^{21}$ Landes, WM \& Posner, RA 1989, "An Economic Analysis of Copyright Law", Journal of Legal Study, vol. 18, pp. 326. 
involved in the creating of intellectual goods ("cost of expression" and "cost of reproduction" respectively). ${ }^{22}$ The first one includes the time and effort that authors spend on original creation as well as the cost to the publisher of editing the work. ${ }^{23}$ The second cost includes the costs of printing, binding, and distributing copies of the work. ${ }^{24}$ Intellectual goods (such as music and stories) must be processed into physical forms ("fixation" as we call it) before we could consume them because unlike physical products, intellectual goods are not in and of themselves physical commodities. Therefore, these costs vary with the number of reproduced goods increases. ${ }^{25}$

Note that one of the ultimate objectives that an author creates is to fulfill his economic goal. ${ }^{26}$ Under the current copyright regime, the decision that whether or not the author is to create new intellectual goods is dependent on the fact that whether the author knows what the demand for the work would be. ${ }^{27}$ It means that the author must compare between the cost of expression and the difference between the profits of selling intellectual goods and the cost of reproducing them. ${ }^{28}$ Therefore, a corollary is that the author will continue to reproduce his works until the marginal cost of reproducing one more copy exceeds the marginal revenue. ${ }^{29}$ Only the author can cover the cost of his creation, including a reasonable return on fixed-cost investment, will he continue to produce more work.

Then we will analyze the incentive to create in the absence of copyright protection. Suppose a world without copyright protection, as under a copyright regime, the author will still have to consider the cost of expression, the cost of making copies, and the expected revenue. ${ }^{30}$ Because the cost of reproducing of a work is so low and the way of disseminating it is numerous, whereas the cost of negotiating the terms of use with the creator and receiving the license is so high, free riding will emerge. A free rider is a person who receives the benefit of a good

22 Ibid.

${ }^{23}$ Ibid. Also see Taylor, A 2007-2009, “Defeating Market Failure: Creating Successful Markets by Encouraging Market Creation by Individual Copyright Holders", Adelphia Law Journal, vol. 16, pp. 41.

24 Ibid.

25 Ibid.

26 Landes and Posner (N 21) 326.

27 Id 327.

28 Ibid.

29 Taylor (N 23) 41.

30 Landes and Posner (N 21) 326. 
but avoids paying for it. ${ }^{31}$ It is understandable that if a potential customer believes that he can obtain a product for free he is unlikely to pay anything for it. ${ }^{32}$ For the sake of the author's interest, of course he could market his work at a price that is close to the marginal cost of his creation, he could not, however, reclaim the cost of his effort in this way. On the other hand, the ability that an author controls his intellectual product is relatively weak comparing with those physical products. This leads to the fact that the producers of such goods can reproduce and sell them at a low cost; it means that those producers who do not pay the author could price the goods cheaper than those who do pay royalty to the author. The existence of free riding does discourage the author from producing works because the cost of expression is likely to exceed the difference between the profits of selling and the cost of reproduction.

\subsection{THE PROBLEM OF PUBLIC GOODS}

The existence of free riding stems from the presence of public goods. Even with the existence of copyright system, it is known that the actual production as well as consumption of intellectual goods would be lower than the ideal level. This underproduction and underconsumption is also the result of public goods as well. Copyright products have long been considered as public goods. A public good features neither excludable nor rival in consumption. ${ }^{33}$ Non-excludability means that a person cannot be prevented from using the good. Because it is rather difficult and expensive to prohibit users from free riding, public goods usually will be under-produced if left to the private market. ${ }^{34}$ Non-rivalry is the state that one person's utilization cannot diminish other people's use. As a result, consumers who would like to consume a public good should be allowed to consume it so long as they are willing to pay the costs of reproduction. Once a copyrighted good is produced, it is subject to the characteristics of public goods. It is generally acknowledged that common resources can be depleted if overuse occurs. The reason for that is that there is no cost to society in letting an individual consume a unit of a non-rivalrous good,

\footnotetext{
Mankiw (N 3) 226.

32 Gordon, WJ 1991-1992, “Asymmetric Market Failure and Prisoner's Dilemma in Intellectual Property" University of Dayton Law Review, vol. 17, pp. 854.

33 Mankiw (N 3) 224.

34 Gordon (N 6) 1611.
} 
since there is no diminution in the possible consumption choices of anyone else. $^{35}$

Books and music, as well as other copyrightable goods, exhibit certain public goods characteristics. ${ }^{36}$ Once the content of the work is made available to the public, the sequence of the word as well as the rhyme of the composition can be used by numerous users while one single use will not exhaust the use of others. At the same time, no one is entitled to deprive the right to use a work by others (no matter in whatever forms). As a result, physical control of intellectual goods proves less efficient in terms of preventing free riding than that of tangible goods. ${ }^{37}$

Another highly relevant issue in the face of non-rivalrous goods is that there is no practical mechanism that will produce the ideal number of reproductions for any given title. ${ }^{38}$ In other words, public goods are expected to be produced at a level that is lower than the socially ideal one. Note that every product that has a value that is higher than its costs of production will be produced in an ideal world. ${ }^{39}$ As a matter of fact, however, no any single producer is capable of appropriating the full benefit of the good. This is so because different consumer values the price of the good differently, resulting in the fact that those who value the price of the good lower than their expectation would not consume. Consequently, some intellectual products will not be produced. ${ }^{40}$ Albeit the establishment of collective management system was somewhat fortuitous, if not totally ignorant about the above issues, it is designed for the goal of overcoming the inherent drawbacks of public goods.

Market failure also results from the presence of free riding. ${ }^{41}$ According to Wendy J. Gordon, market failure first occurs when there is no legal rule that requires copyists to seek permission and pay license fees. ${ }^{42}$ With the presence of a copyright law and some other rules prohibiting unauthorized users from copying, free riding would be excluded to some

35 Liebowitz, S 2005, “MP3s and Copyright Collectives: a Cure Worse Than the Disease?" in Takeyama, LN, Gordon, WJ \& Towse, R (eds.), Developments in the Economics of Copyright: Research and Analysis Edward

36 Gordon (N 6) 1611.

37 Ibid.

38 Liebowitz (N 35) 44.

39 Ibid.

40 Ibid.

41 Lemley, MA 2004-2005, “Property, Intellectual Property, and Free Riding", Texas Law Review, vol. 83, pp. 1032.

42 Gordon (N 32) 854. 
extent. This is particularly important because with more and more free riders, authors find production increasingly unmotivated and thus decrease the amount of works they produce. Subsequently, the supply of these goods drops - while the demand curve remains the same, leading to the decrease of the total surplus. This fall in total surplus is also a deadweight loss because it results from a market distortion.

\subsection{CMOS' PRICE DISCRIMINATION STRATEGY IN THE FACE OF PUBLIC GOODS}

Traditional economic literature contends that taxation and government provision might provide a satisfactory solution to the problem of public goods. ${ }^{43}$ That is to say that government can provide the public good or pay for it with tax revenue if the government decides that the total benefits of a public good exceed its costs. ${ }^{44}$ Nonetheless this approach is inappropriate for much intellectual property. ${ }^{45}$ Freedom of expression is the main core of copyright creation, once it is compromised to governmental reprisal, there is a danger of lacking democracy. ${ }^{46}$ Moreover, Governmental subsidy might be arbitrary. Government might tend to subsidize those works of much utilization such as those of a scientific nature. ${ }^{47}$

Another effective approach in order to offset the negative externality that public goods bring is to price discriminate consumers. Before we begin our discussion of this issue, note that first of all price discrimination is not possible when a good is sold under a competitive market because in a competitive market, goods are sold at the market price. ${ }^{48}$ In a competitive market, the producer will determine the uniform price on the basis of his marginal cost of producing one more product. Once the marginal cost equals the marginal revenue, he will set this market price so that consumer demand will equal his output. ${ }^{49}$ Price discrimination - with which a profit-maximizing producer with market power will set his price at a level that is higher than his marginal cost, ${ }^{50}$ however, is a rational

43 Gordon (N 6) 1611.

44 Mankiw, NG 2009, Principles of Economics, 5th edn. Cengage Learning Asia Pte Ltd, pp. 228.

45 Gordon (N 6) 1612.

46 Ibid.

47 Tyerman, BW 1970-1971, “The Economic Rationale for Copyright Protection for Published Books: A Reply to Professor Breyer", UCLA Law Review, vol. 18, pp. 1117.

48 Mankiw (N 44) 326.

49 Lunney, Jr., GS 2007-2008, “Copyright's Price Discrimination Panacea”, Harvard Journal of Law $\mathcal{E}$ Technology, vol. 21, pp. 396.

50 Ibid. 
strategy for a monopolist. ${ }^{51}$ That is, by selling goods at a price closer to the willingness to pay by different customers - or even charge a single consumer a different price for each unit purchased, ${ }^{52}$ a price-discriminating monopolist could be selling more products than with a single price. ${ }^{53}$ No doubt that different consumer values the price of a product differently, they only make the decision of consuming when they value the product higher than the reservation price of it. By pricing differently, the producer aims at satisfying the demand of differing consumers in the hope of eliminating free riding to some extent. A corollary to this is that price discrimination could thus raise social welfare because price discrimination has the potential of increasing not only the profits of producers but also the circulation of intellectual goods. ${ }^{54}$ In other words, price discrimination is Pareto efficient when a monopolist exists and thus eliminates the deadweight loss associated with uniform pricing. ${ }^{55}$

The licenses granted by CMOs are a typical type of price discrimination. Traditional speaking, a CMO grant three types of licenses, per use contracts, per program contracts, and blanket licenses. ${ }^{56} \mathrm{~A}$ per use contract targets those users who intend to use a work for a single time. Every time utilization is made, a specific royalty payment would be followed. Under per program contract, however, once the terms of the contract are made, an individual work or classes of works could be utilized for unlimited time. On the other hand, blanket licensing is described as a "bundle of copyrights", ${ }^{57}$ which does not allow users to select among works. ${ }^{58}$ Once a blanket license is granted, users are entitled to unlimited use all the works available in the repertory of the CMOs. ${ }^{59}$ Collecting societies typically charge users a royalty from a tariff of elaborate categories (e.g., the size of the premises, the audience, and the purpose of the utilization). ${ }^{60}$

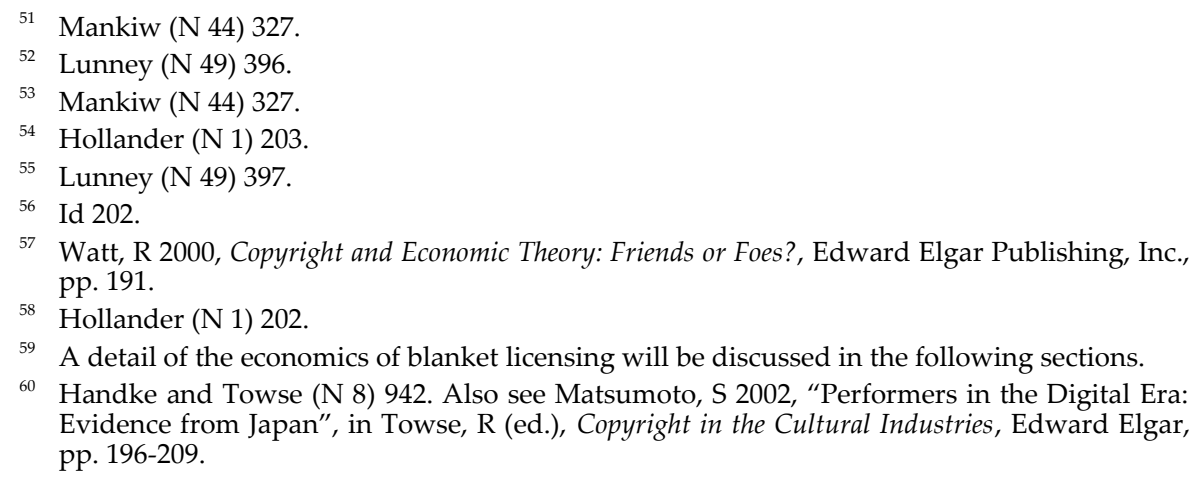

57 Watt, R 2000, Copyright and Economic Theory: Friends or Foes?, Edward Elgar Publishing, Inc., pp. 191.

58 Hollander (N 1) 202.

59 A detail of the economics of blanket licensing will be discussed in the following sections.

${ }^{60}$ Handke and Towse (N 8) 942. Also see Matsumoto, S 2002, "Performers in the Digital Era: Evidence from Japan", in Towse, R (ed.), Copyright in the Cultural Industries, Edward Elgar, pp. 196-209. 
Moreover, they will also analyze the willingness and ability to pay by users on the basis of the information and data (concerning the number of uses and the value generated) collected to evaluate their license fees. ${ }^{61}$ Price discrimination by CMOs thus eliminates the number of potential users that would be excluded from purchasing a license because of a uniform license fee that would be more expensive than their reservation price. ${ }^{62}$ Under perfect price discrimination, which means that the producer knows exactly the willingness to pay of each consumer and charges each consumer a differing price, ${ }^{63}$ no user would thus be excluded from licensing. As a result of the fact that surplus transfers from consumers to producers (i.e., right holders and CMOs), price discrimination shows up as the entire surplus derived from the market goes to the producer in the form of profit without any deadweight loss. ${ }^{64}$

Although perfect price discrimination does not exist in real world because of the costly information that is needed to process, digital rights management (DRM) technologies employed by CMOs nevertheless help solve this problem. DRM systems are designed to control access to and use of digital content such as video, music, or computer software. ${ }^{65}$ By implementing DRM technologies, CMOs are able to assess the use of individual works much more precisely and thus make more accurate predictions upon the preference of different works. It is enabled by encryption techniques that allow right holders to record and track down the behaviors of the users. This helps the pricing of differentiated works and further facilitates price discrimination. It should also help improve the process of market signaling so that supply would be more tightly linked to paying consumers tastes. ${ }^{66}$ In addition, the "menu costs" (that is, the costs accrued through a price change $)^{67}$ are reduced since price change is based on a more reasonable calculation, which also facilitates price discrimination.

To summarize, by managing the works in their repertoire collectively, CMOs indirectly strengthens right holders' control of their works.

${ }_{61}$ Handke and Towse (N 8) 942.

62 Ibid.

${ }^{63}$ Mankiw (N 44) 328.

${ }^{64}$ Ibid. Also see Lunney (N 49) 398.

65 Katz, A 2006, "The Potential Demise of Another Natural Monopoly: New Technologies and the Administration of Performing Rights", Journal of Competition Law \& Economics, vol. 2, pp. 248.

${ }^{66}$ Handke and Towse (N 8) 949.

67 Hansen and Schmidt-Bischoffshausen (N 14) 470. 
As a matter of fact, managing intangible property rights is much more difficult than their tangible counterparts. Once the form and content of the work is publicized, it can be utilized by differing subjects under specific circumstance. Depending on their wide range representative ability and influential market power, collecting societies grant various types of licenses to large number of users on the basis of the collection of right holders and their creations as many as possible. This to some extent meets the end need of right holders, whose demand and willingness is to publicize and take necessary control of their products in order to make full use of their products. From this perspective, collective management of copyright internalizes one of the externalities of copyright management.

In addition, as mentioned above, the contrast between the very high cost of creation and the relatively low cost of reproduction breeds free riding, which in return harms the enthusiasm of copyright holders and damages the infrastructure of copyright system. Things may become even worse in digital era since dissemination of pirated copies is rampant all over the world. The existence of CMOs, however, prevents the out-of-order utilization of copyrighted works and at the same time ensures their publicness by granting various licenses and by collecting different license fees confronting different users and different purposes. As a consequence, with free riding being eliminated to a large extent, the economic interest of copyright holders is protected and the total surplus increases.

\section{COLLECTIVE MANAGEMENT ORGANIZATIONS IN THE FACE OF TRANSACTION COSTS}

Economists always see CMOs as an efficient way of overcoming the problem of high transaction costs for administering copyright in some markets. ${ }^{68}$ In order to measure the transaction costs involved in copyright management, one must initially define and critically appreciate the theoretical basics of the transaction cost approach as well as the concept of transaction costs. ${ }^{69}$

\subsection{GENERAL BACKGROUND OF TRANSACTION COSTS}

When it comes to transaction cost, one cannot ignore the great contributions presented by Nobel Prize winner Ronald H. Coase. In his thought

\footnotetext{
68 Handke and Towse (N 8) 938.

${ }_{69}$ Hansen and Schmidt-Bischoffshausen (N 14) 464.
} 
provoking essays "The Nature of the Firm" in $1937^{70}$ and "The Problem of Social Cost" in $1960^{71}$, Coase laid the foundation of transaction cost approach. According to the Coase theorem, if private parties can bargain without cost over the allocation of resources, they can solve the problem of externalities on their own. ${ }^{72}$ In other words, one must assume that on the basis of missing transaction costs, private negotiations will lead to a more efficient allocation of resources than state interventions. ${ }^{73}$ In the real world, however, costs will accrue in every transaction because in order to carry out a market transaction it is necessary to discover various information concerning both parties of the transaction. For example, Coase suggests that one has to "discover who it is that one wishes to deal with, toiinform people that one wishes to deal and on what terms, to conduct negotiations leading up to a bargain, to draw up the contract, to undertake the inspection needed to make sure that the terms of the contract are being observed, and so on. These operations are often extremely costly, sufficiently costly at any rate to prevent many transactions that would be carried out in a world in which the pricing system worked without cost." ${ }^{74}$ When transaction costs are high enough to prevent bargaining, the efficient use of resources will depend on how property rights are assigned. ${ }^{75}$

If the transaction costs are so high that they exceed the benefit of contracting, then the reasonable person will choose not to carry out this transaction. There is no doubt that cooperation creates more benefits than non-cooperative actions, because each side will benefit to some extent. However, when transaction costs are taken into consideration, both sides in the contract have to make sure that their potential cooperative benefits exceed the costs accrued. Otherwise, no transaction could be made under the context in which a homo oeconomicus pursues profit-maximizing strategy. Therefore, the level of transaction costs plays an important role in individual negotiation and enforcement of contract, whereby individual achievement of transaction facilitates the efficiency of the society as a whole. The aim of transaction costs analysis is to identify possible ways of cost saving so that parties can reduce the costs induced in the making

70 Coase, RH 1937, “The Nature of the Firm”, Economica, vol. 4, pp. 386.

71 Coase, RH 1960, "The Problem of Social Cost", Journal of Law and Economics, vol. 3, pp. 1.

72 Mankiw (N 3) 210.

73 Hansen and Schmidt-Bischoffshausen (N 14) 464.

74 Coase (N 71) 15.

75 Cooter, R \& Ulen, T, Law \& Economics, 5th Edition Pearson, pp. 89. 
of agreement. ${ }^{76}$ In terms of collective management of copyright, transaction costs analysis attempts to facilitate the identification of right holders and potential users, the negotiation of terms and licenses, the enforcement of contracts, the collection and distribution of royalties, and if necessary, the litigation of infringement. It makes sure that the access to copyrighted works and the dissemination of knowledge move smoothly so that the goal of copyright law achieved.

Professor Oliver Williamson introduces three specific criteria in order to evaluate the level of transaction costs: (1) uncertainty, (2) the frequency with which transactions recur, and (3) the degree to which durable, transaction-specific investments (asset specificity) are required to realize least cost supply. ${ }^{77}$ In most market transactions, uncertainty results from the information situation regarding the contractual partner or the details of the contract ${ }^{78}$ while frequency can be characterized as onetime, occasional, and recurrent. ${ }^{79}$ Note that the more information required to be discovered (as the result of the larger market and the more dynamic social context), the more costs accrued by this transaction. Williamson particularly points out that items that are specialized among users (i.e. asset specific) pose more hazards as buyers under this circumstance find them more difficult to turn to alternative sources and sellers cannot sell their goods intended for one buyer to other buyers without difficulty. ${ }^{80}$

\subsection{CATEGORIES OF TRANSACTION COSTS}

There are three types of transaction costs incurred corresponding to the development of an exchange: (1) search costs, (2) bargaining costs, and (3) enforcement costs. ${ }^{81}$

Search costs accrue in the soliciting of a potential contracting partner. ${ }^{82}$ Generally speaking, search costs tend to be high for unique goods or services, and low for standardized goods or services. ${ }^{83}$ The number

\footnotetext{
76 Hansen and Schmidt-Bischoffshausen (N 14) 464.

77 Williamson, OE 1981, "The Economics of Organization: The Transaction Cost Approach", The American Journal of Sociology, Vol. 87 No.3, pp. 555. Williamson, OE 1979, "Transactioncost Economics: The Governance of Contractual Relations", Journal of Law $\mathcal{E}$ Economics, vol. 22, pp. 246.

78 Hansen and Schmidt-Bischoffshausen (N 14) 466.

79 Williamson (1979) (N 77) 246.

80 Williamson [1981] (N 77) 555.

${ }^{81}$ Cooter and Ulen (N 75) 91.

82 Hansen and Schmidt-Bischoffshausen (N 14) 464.

${ }^{83}$ Cooter and Ulen (N 75) 92.
} 
of copyright holders is numerous. Comparing with it, however, the number of copyrighted works can be much larger because each author probably creates more than one work. The idiosyncrasy of copyrighted works makes the boundary of each work difficult to define because original expression is another thing that is without clear definition. As a result, observers often infringe copyrighted works by mistake. Thanks to copyright laws, which do not require owners' exhaustive description of copyrighted goods, this to some extent lowers the search costs on observers. However, the fact that potential users will still need to learn about the attributes of an intellectual good to avoid infringing $\mathrm{it}^{84}$ and to determine whether they want to enter into negotiations with the property owner over it ${ }^{85}$ will accrue costs as well, e.g. opportunity costs such as determining not to contract with another right holder. Potential users must also make secondorder decisions regarding how much information to collect before making decisions regarding the good. ${ }^{86}$ Because there is myriad number of works available, users have to find appropriate licensors and make contact with them so that following negotiation can proceed, especially when authors are hardly known or anonymous, this licensee might confront with even more search costs. On the other hand, the search costs incurred by right holders can also be prohibitively high. Once a potential user conveys the intention to negotiate an agreement, information about him and his conditions have to be tracked down. Through the time and money spent on collecting this information, there is possibility that subsequent establishment of contact will occur. ${ }^{87}$ In addition, informed costs have to be calculated carefully. Laws require owners that they are obliged to disclose appropriate information about their goods (e.g., such information include the serial number of the book, the personal information about the author, etc., through advertisements available on broadcast or Internet). Moreover, in case that third party users use the works protected by copyright law illegally, right holders have to spend money on detecting infringed uses so that they are able to claim compensation, and where necessary, law suits.

When the contracting parties have been located, bargaining costs accrued for the negotiation and concluding of the contract. The terms

${ }^{84}$ Long, C 2004, "Information Costs in Patent and Copyright", Virginia Law Review, vol. 90, pp. 476.

85 Ibid.

86 Ibid.

87 Hansen and Schmidt-Bischoffshausen (N 14) 465. 
of the contract such as the date of delivery, payment, and after-sale service are the costs of drawing up a contract. ${ }^{88}$ Generally, negotiations tend to be simple and easy when information about the threat values and the cooperative solution is public. ${ }^{89}$ However, this may not be the case in copyright regime because many of the information tend to be private, ${ }^{90}$ i.e. the seller of copyrighted product knows a lot more about its hidden information than the buyers know, whereas the buyer knows a lot more about his or her ability to obtain financing than the seller knows. ${ }^{91}$ This requires the parties of negotiation convert the private information into public information before computing reasonable terms for cooperation ${ }^{92}$ and thus costs accrued. To facilitate the negotiation, the parties may divulge some of the information they have. But for the sake of their own interest, it is impossible for them to divulge all because keeping some information private does matter during negotiating a contract. Keeping the balance of public and private information is therefore expensive.

Generally speaking, most of the contracts only concern two parties. Negotiating terms between two parties is usually easy and cheap in terms of distance. However, many bargains involve three or more parties, especially in the copyright industry because rights are dispersed in this area (e.g. a user has to negotiate with performer, composer and lyricist before being granted a user license, things become even more difficult if there exist co-authors). This characteristic of copyrighted products increases the costs of negotiation exponentially. What's more, the costs of drafting the specific terms in an agreement are costly since they require the anticipation of many contingencies that can arise to change the value of the bargain. ${ }^{93}$ In particular, agreement on terms concerning the price of products - which are dependent mainly on the supply and demand curve of this product - is especially difficult to achieve.

Enforcement costs are costs accrued in order to ensure the agreement is fulfilled. One party must keep watching the other to make sure that he keeps his promise. In other words, the execution of the contract follows

\footnotetext{
${ }^{88}$ Harrison, JL \& Theeuwes, J 2008, Law \& Economics, W. W. Norton \& Company, Inc., pp. 91.

89 Cooter and Ulen (N 75) 92.

90 Ibid. Keeping the information public means that both parties know each other's threat values and the cooperative solution. Keeping the information private means that one party knows some of the values and the other does not.

91 Ibid.

${ }_{92}$ Ibid.

93 Id 93.
} 
the stipulation of the agreement (e.g. the execution time, quality and payment method). It is possible that the terms of the agreement become not applicable since the situation changes, especially in the long term. In this sense, the contracting parties have to pay extra effort to amend these terms so that the aims of the contract remain. There are also costs of dealing with noncompliance and breach of contract. $^{94}$ Once noncompliance of contract is detected, costs dealing with legal remedies and law suits may occur. In general, enforcement costs are low when violations of the agreement are easy to observe and punishment is cheap to administer. ${ }^{95}$

\subsection{TRANSACTION COSTS REDUCED BY COLLECTIVE MANAGEMENT ORGANIZATIONS}

It is suggested that the high costs of contracting drive the right holders to pool their property rights in a collective organization..$^{96}$ Indeed, certain kinds of rights cannot be enforced by individual right holders unless they join together for collective enforcement. ${ }^{97}$ As the consequence of establishing a collective, authors no longer enter the market as individuals, which empowers them more abilities than contracting individually when negotiating with music publishers and users. ${ }^{98}$

Proponents for collective management of copyright argue that individual management of copyright is sometimes impossible because it imposes too much burden on both the owners and users. They believe that in the face of a vast number of works and parallel uses (e.g. public performance or mechanical performance, etc.), it is practically impossible for individual right holder to record every use of the work. ${ }^{99}$ For example, Abada contends that

"as an individual acting alone in today's society, characterized by the wide range of means available for using works of the mind and the frequency of their simultaneous exploitation both at home and abroad, an author

94 Harrison and Theeuwes (N 88) 91.

95 Cooter and Ulen (N 75) 94.

96 Merges, RP 1996, “Contracting into Liability Rules: Intellectual Property Rights and Collective Rights Organizations", California Law Review, vol. 86, pp. 1302.

97 Besen, SM \& Kirby, SN 1989, "Compensating Creators of Intellectual Property: Collectives That Collect", The RAND Corporation, pp. 2.

98 Watt, R 2010-2011, “Copyright and Contract Law: Economic Theory of Copyright Contracts", Journal of Intellectual Property Law, vol. 18, pp. 202.

99 Hansen and Schmidt-Bischoffshausen (N 14) 467. 
cannot effectively ensure that his rights are protected... authors must organize themselves, either at their own initiative or at that of the State, within bodies that will collectively administer their rights. "100

Tournier and Joubert also argue that

"... it is obvious that it would be utopian to imagine that an author could undertake the individual administration of each of his musical works, even on the territory of the country to which he belongs, and therefore only collective administration of the repertoire of musical works by a specific centralizing body is materially, economically and legally practicable." 101

On the other hand, the costs spent by potential users would be considerably high. For example, it is often the case that sellers know more about the quality of goods than do buyers. ${ }^{102}$ In the copyright industry, sometimes third parties might conceal the information concerning the particular work (e.g. impersonating as the author of the work), which the users are difficult to find out. This information asymmetry can disrupt market so much that a social optimum cannot be achieved. ${ }^{103}$ Volunteer exchange of information might correct this defect of market though; this is extremely impractical if people find concealing lucrative.

Granting license has been considered one of the most costly aspects in copyright management though, collective management of copyright can effectively handle this issue. Under collective management, there is typically only one $\mathrm{CMO}$, which grants licenses to potential users in one specific domain of rights. An access to the world repertory is possible through the reciprocal agreement made between one local CMO and its counterparts in other countries. ${ }^{104}$ This means that users are capable of using all the works available in different repertoires through one license. With right holders' information recorded by the $\mathrm{CMO}$, the hurdles that involved in the very first stage of licensing (including complex assignment of partial legal rights and license drafting) ${ }^{105}$ are thus overcome, because identifying who the proper parties to a license are would not become

\footnotetext{
100 Abada, S 1985, "Collective Administration of Author's Rights in the Developing Countries", Copyright, vol. 21, pp. 314.

101 Tournier, J. L. \& Joubert, C 1986, "Collective Administration and Competition Law", Copyright, vol. 22, pp. 98.

${ }^{102}$ Cooter and Ulen (N 75) 47.

103 Ibid.

104 Watt (N 98) 200.
} 
a significant problem. ${ }^{106}$ Negotiating with a particular user and monitoring him thus transforms into a way that the collective on behalf of all members with each of them bearing only a small fraction of the cost negotiates. ${ }^{107}$

Further, adoption of uniform or template contract by $\mathrm{CMO}$ reduces bargaining and enforcement costs. It is suggested that through standardization of contracts the per-unit cost can be reduced ${ }^{108}$ and given contractual terms offered by collecting societies lower the costs of exchange with users. ${ }^{109}$ The obligation that under specific conditions CMOs could not deny granting licenses to potential users imposes legal certainty upon all involved parties. By requiring right holders and users comply with standard form contracts, users are able to exploit copyright works with a fixed royalty paid, thereby economizing the bargaining costs of negotiating detailed terms with CMOs accrued otherwise. ${ }^{110}$ At the same time, the organization's internal rules that stipulate tariff rates save on member-to-member transaction costs. ${ }^{111}$ By relying on established administrative mechanisms, both owners and users find it easier when it comes to collection and distribution of royalties. Moreover, given the fact that collecting societies are usually specialized in their field of licensing and they are sensitive to the interests of the authors, they may tend to lobby policy makers in order to make the law tilt more towards right holders. ${ }^{112}$ Thus this internal governance rules and economies of scale in enforcement combined may fully internalize the deterrence effect of a successfu1 lawsuit on potential future infringers. ${ }^{113}$

Collecting societies achieve a further reduction of transaction costs by granting blanket licenses. ${ }^{114}$ A pricing scheme in which users may face different royalty level for licensing different works may be unattractive to users. ${ }^{115}$ Thus a blanket license spares licensees the costs of access

${ }^{105}$ Lemley, MA 1996-1997, “The Economics of Improvement in Intellectual Property Law”, Texas Law Review, vol. 75, pp. 1053.

106 Ibid.

107 Hollander (N 1) 201.

108 Lemley (N 105) 1054.

109 Merges (N 96) 1302.

110 Masiyakurima, P 2006-2007, “The Effectiveness of Judicial Licensing in Copyright Law”, Journal of Copyright Society of U.S.A., vol. 54, pp. 822.

111 Merges (N 96) 1302.

112 Masiyakurima (N 110) 823.

113 Hollander (N 1) 201.

${ }^{114}$ Hansen and Schmidt-Bischoffshausen (N 14) 469.

${ }^{115}$ Besen and Kirby (N 97) 7. 
to the entire repertoire and the cost of every single transaction. ${ }^{116}$ The rationale of a blanket license was delivered by the Supreme Court of the United States:

"Most users want unplanned, rapid, and indemnified access to any and all of the repertory of compositions and the owners want a reliable method of collecting for the use of their copyrights. Individual sales transactions in this industry are quite expensive, as would be individual monitoring and enforcement, especially in light of the resources of single composers."117

CMOs therefore lower transaction costs by imposing low compliance costs on users and providing a one-stop shop service. ${ }^{118}$

The utilization of DRM technologies in managing copyrighted works by CMOs allows a reduction of transaction costs as well. For example, using the technology of "trusted systems" facilitates the cheaply monitor of consumer usage of digital copies (e.g. the number of times a work is accessed) and access "micro-charges"(e.g. e-cash account) for such usage as well. ${ }^{119}$ It is also quite likely that these technical solutions can facilitate substantially the control of legal and illegal uses of intellectual goods. On the contrary, although new technologies make things much easier, collecting societies still take charge of a number of functions that new technologies do not. First of all, collecting societies can help right holders find potential users. Every day hundreds of millions of users are seeking appropriate intellectual works to fulfill their needs - either economically or psychologically. But the fact is that not all users are capable of finding a license that meets their need. In some extreme cases even some professional users who believe their business legitimate start their career without having concluded a license agreement. ${ }^{120}$ Although the advent of some new technologies such as the search engine and data base may help solve this problem to some extent, for the majority of works (i.e., economically less popular works) it still remains difficult to contact

${ }^{116}$ Handke and Towse (N 8) 941.

117 Broadcast Music, Inc. v Columbia Broadcasting Systems, Inc. 441 U.S. 20 (1979).

118 Katz, A 2005, “The Potential Demise of Another Natural Monopoly: Rethinking the Collective Administration of Performing Rights", Journal of Competition Law \& Economics, vol. 1, pp. 572.

119 Liu, JP 2000-2001, “Owning Digital Copies: Copyright Law and the Incidents of Copy Ownership", William \& Mary Law Review, vol. 41, pp. 1320.

${ }^{120}$ Meyer, A 2005, "DRMS Do Not Replace Collecting Societies”, in Graber, CB, Govoni, C, Girsberger, M, and Nenova, M (eds.), Digital Rights Management: The End of Collecting Societies?, Berne: Staempfli Publishers Ltd., pp. 64. 
with the real right holders. With extensive documentation which keeps track of detailed information about the works by the collecting societies, however, the communication between right holders and users can be much more facilitated. In this sense, collecting societies also play the role as the monitor of the entire cultural market. ${ }^{121}$ Copyright collectives also negotiate license fees on behalf of the right owners. Right holders are always at a weaker position in terms of information that they are unfamiliar with situations such as transaction methods, market conditions and transactional risk. At the same time, users very often belong to international media giants or are much strong economically than right holders, leading to a more advantageous position when they are negotiating license agreement. Collecting societies, depending on their monopolistic position derived from the fact that they represent a world repertoire, have a counterbalance effect upon the negative situation right holders face. Finally, collecting societies enforce rights. ${ }^{122}$ The advent of the Internet results in the increase of the costs to protect rights by individual right holder. Right holders have to pay extra money on searching and monitoring the enforcement of their rights. Therefore, they will find it unattractive if the costs to protect their rights prevail the interests they gain by doing so. As regard to this, copyright collectives

"have the means to build up the reputation, by those who refuse to take out a license or pay for it, of not letting go" $^{\prime \prime}{ }^{123}$

In the meantime, collecting societies are also the representatives of right holders fighting piracy.

\section{COLLECTIVE MANAGEMENT ORGANIZATIONS IN THE FACE OF MONOPOLY}

Both the copyright laws and antitrust laws aim at promoting innovation, nevertheless these two regimes of laws tend to realize this goal through conflicting methods. Copyright laws, on the one hand, grant right holders a monopolistic right - the exclusive right to perform and to authorize others to perform their works - in order to incentivize creativity. On the contrary,

\footnotetext{
121 Ibid.

122 Ibid.

123 Ibid.
} 
antitrust laws enhance innovation by removing restrains on competition and thus discouraging monopolization. ${ }^{124}$

As a matter of fact, although in most countries there are several colleting societies there is only one collective for each category of copyright (e.g. performing rights, reprography rights, etc.). ${ }^{125}$ Exception can be found in the U.S.A., where there are three major performing rights organizations competing with each other (i.e. the American Society of Composers, Authors and Publishers (ASCAP), Broadcast Music, Inc. (BMI), and SESAC, Inc. (formerly the Society of European Stage Authors and Composers)). ${ }^{126}$ In those countries where there is only one collective managing one particular type of copyright, the issue of monopolization exists. Several users groups even filed lawsuits against collecting societies, alleging they abused their monopolistic positions. Inter alia, the CISAC (International Confederation of Societies of Authors and Composers) case is the most prominent one.

\subsection{THE CISAC CASE}

The so-called "CISAC Case" was a competition law case brought by the EU Commission against a group of authors' societies in Europe. The case, which commenced with two separate complaints filed with the EU Commission by commercial users, focused on the reciprocal representation agreements signed between these societies. ${ }^{127}$ Specifically, the first complaint was filed by RTL Group (German Broadcaster) in 2000 against German authors' society GEMA's refusal to grant a community-wide license for the performing rights it administers on behalf of its members and foreign authors. ${ }^{128}$ The second complaint was filed by Music Choice (digital music provider) in 2003 against CISAC arguing that certain provisions in the CISAC Model Contract for reciprocal representation prevented societies from granting multi-territory licenses and thus violated EU competition rules. ${ }^{129}$

The Commission issued its decision in 2008, which alleged that

\footnotetext{
124 Kennedy, MK 1984, "Blanket Licensing of Music Performing Rights: Possible Solutions to the Copyright-Antitrust Conflict", Vanderbilt Law Review, vol. 37, pp. 184.

125 Watt (N 57) 177.

126 Ibid.

${ }^{127}$ CISAC official website, $<$ http://www.cisac.org/Cisac-University/Legislation/The-CISAC-Case>.

128 Ibid.

129 Ibid.
} 
"the societies had engaged in concerted practices and illegally reached an arrangement on the territorial scope of their respective reciprocal representation agreements. ${ }^{\prime 130}$

This arrangement prevented the societies from competing with one another in the grant of multi-territorial, multi-repertoire licenses for digital rights exploitation of performing rights. ${ }^{131}$ In addition, the Commission further argued that

"societies prevented authors from joining the society of their choice and prevented each other from issuing licences for their own repertoire outside the territory in which they are based." 132

Upon the decision CISAC delivered its strong opposition and appealed the decision before the EU General Court. The focal point of these appeals was that CISAC denied the allegation that societies had engaged in a concerted practice by coordinating the territorial scope of their reciprocal representation agreements. ${ }^{133}$

On April 12, 2013, the General Court of the EU issued its ruling in the appeal, which annulled the 2008 decision of the EU Commission. CISAC put forward the key arguments against this decision, which contained

"(1) infringement of Article 81 EC and of Article 253 EC, in that the Commission has not proved the existence of a concerted practice with regard to the national territorial limitations, and (2) in the alternative, infringement of Article $81 \mathrm{EC}$, in that the concerted practice, even if it were to exist, would not be restrictive of competition."134

The Court agreed with CISAC on both arguments. With respect to the evidential value of the elements put forward by the Commission to prove the existence of the concerted practice without relying exclusively on parallel conduct of the collecting societies, the Court confirmed that

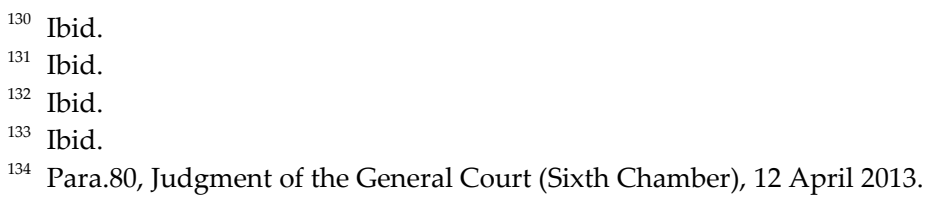


"the mere fact that collecting societies met in the context of the activities managed by the applicant and that there is a certain amount of cooperation between them does not constitute, as such, evidence of prohibited concertation. Where the context in which meetings between undertakings accused of infringing competition law take place shows that those meetings were necessary to collectively deal with issues in no way related to such infringements, the Commission cannot presume that the object of those meetings was to focus on anti-competitive practices. In that respect, it must be observed that the Commission has not provided any evidence that the meetings organised by the applicant concerned the restriction of competition relating to the national territorial limitations." 135

Moreover, in the absence of evidence that the collecting societies acted in concert for that purpose, the return to national territorial limitations does not demonstrate the existence of concertation relating to the national territorial limitations. ${ }^{136}$

The Court also accepted that societies have very good reasons to mandate a single society with a local presence in each foreign territory, ${ }^{137}$ because to provide for territorial limitations in the collecting societies' reciprocal representation agreements was a means of ensuring the effectiveness of the fight against the unauthorized use of musical works. ${ }^{138}$ Pursuant to the applicant, the collecting society best able to carry out the task of managing the general monitoring of the market in order to require users to request licenses, is, for each territory, the local collecting society, which has the most thorough knowledge of the market of the country in which it is established. ${ }^{139}$ Additionally, the guarantee that recovers the expenses related to the monitoring which it carries out, would be threatened if several collecting societies could grant for the same territory licenses covering the same repertoires. ${ }^{140}$ The Court adopted CISAC's arguments. Finally, the Court discovered that there were incentives that a society would not want to organize competition over its

\footnotetext{
135 Id Para.107.

136 Id Para.110.

137 Oron, G, "CISAC Case: Analysis of Court Ruling", $<$ http://www.cisac.org/Newsroom/Articles/CISAC-Case-Analysis-of-Court-Ruling>.

${ }^{138}$ Para.140, Judgment of the General Court (Sixth Chamber), 12 April 2013.

139 Id Para.150.

140 Ibid.
} 
own rights in a given territory and thus opened the door for the development of new multi-territory licensing models. ${ }^{141}$

The aim of the Commission proposing the multi-territorial licensing (MTL) was to foster competition. With respect to this aim, the Commission proposed a Directive

"on collective management of copyright and related rights and multiterritorial licensing of rights in musical works for online uses in the internal market", ${ }^{142}$

of which Title III is aim at enabling and indeed promoting the granting by collecting societies of MTL for online rights in musical works. ${ }^{143}$ The CISAC decision in this regard thus significantly impacted upon the legislative process regarding MTL. It is commented by the Max Planck Institute for Intellectual Property, Competition and Tax Law that

"a system based on competition in the market for collective management services to rightholders has broken the foundations of collective rights management as it had developed. The previous system emerged because it adequately responded to the economic needs of both rightholders and users". ${ }^{144}$

Therefore, the CISAC decision undermines the Commission's justification for the proposed MTL system. On the contrary, it seems that the national territorial limitations are more favorable as they have presented more effective outcome, which worth reconsideration. ${ }^{145}$

141 Oron (N 137).

${ }^{142}$ Proposal for a DIRECTIVE OF THE EUROPEAN PARLIAMENT AND OF THE COUNCIL on collective management of copyright and related rights and multi-territorial licensing of rights in musical works for online uses in the internal market, $\operatorname{COM}(2012) 372$ final, <http://ec.europa.eu/internal_market/copyright/docs/management/com-2012-3722_en.pdf>. In March 20, 2014, the European Commission finally promulgated the official Directives, $<$ http://eur-lex.europa.eu/legal-content/EN/TXT/PDF/?uri=CELEX:32014L0026\&from=EN>.

143 Ibid.

${ }^{144}$ Drexl, J, Nerisson, S, Trumpke, F, and Hilty, RM “Comments of the Max Planck Institute for Intellectual Property and Competition Law on the Proposal for a Directive of the European Parliament and of the Council on Collective Management of Copyright and Related Rights and Multi-Territorial Licensing of Rights in Musical Works for Online Uses in the Internal Market COM (2012)372", Max Planck Institute for Intellectual Property and Competition Law Research Paper No. 13-04, para. 64.

145 Quintais, JP 2013, “The Empire Strikes Back: CISAC Beats Commission in General Court”, Journal of Intellectual Property Law \& Practice, pp. 683. 


\subsection{THE DILEMMA OF MONOPOLISTIC POSITION OF CMOS 4.2.1 THE NEGATIVE EFFECT OF MONOPOLY}

Let us discuss the price that a collective will collect under the monopolistic situation first. Note that the only product that a CMO sells is the license. Therefore, the price of a license does have significant impact upon the supply and demand of intellectual goods. Economic theory tells us that a monopolist like other rational people will think at the margin. ${ }^{146}$ If the marginal cost of granting a license is less than its marginal revenue, the collective can increase profit by increasing its production. By contrast, if the marginal cost of granting a license is greater than its marginal revenue, the collective can raise profit by reducing production. Consequently, the CMO adjusts its level of production (in this sense, the granting of license) until the quantity reaches its maximum, at which marginal revenue equals marginal cost. Thus, the monopolist's profitmaximizing quantity of output is determined by the intersection of the marginal-revenue curve and the marginal-cost curve. ${ }^{147}$

Note that in following the rule for profit maximization, both competitive and monopolistic CMOs are alike. What is different is that the marginal revenue of a competitive $\mathrm{CMO}$ equals its price, while the marginal revenue of a monopolistic CMO is less than its price. ${ }^{148}$ This leads to the price differentiation. After the monopoly CMO chooses the quantity of output that equals marginal revenue and marginal cost, it uses the demand curve to find the highest price it can charge and sell that quantity. ${ }^{149}$ In other words, price equals marginal cost in competitive markets whereas price exceeds marginal cost in monopolized markets. ${ }^{150}$ As a corollary, monopoly prices are widely considered to be socially undesirable because of their alleged effects on income distribution, overall economic stability, the allocation of economic resources, and proper business incentives. ${ }^{151}$

When it comes to the production of the economically efficient number of intellectual goods, a monopolistic CMO seems unsatisfatorily performed

\footnotetext{
${ }^{146}$ Mankiw (N 44) 319.

147 Ibid.

148 Id 320.

149 Ibid.

150 Ibid.

151 Posner, RA 1968-1969, “Natural Monopoly and Its Regulation”, Stanford Law Review, vol. 21, pp. 550.
} 
in this regard. Besen, Kirby and Salop ${ }^{152}$ raise the question whether CMOs should operate as clubs that control the size of their membership or whether all right holders should be entitled to join the society. ${ }^{153}$ In their analysis, they argue that because the collecting society must balance the decline in revenue per member as the repertoire of the $\mathrm{CMO}$ enlarges against the decline in costs per member as the administrative costs are spreaded among members, the maximum surplus per member will be achieved at a point where the effect of diminishing returns equal the effect of spreading fixed cost. ${ }^{154}$ As a result, in a closed monopolistic collective, the size of the collective (that is, the number of works available to be licensed) is supposed to be smaller than the socially efficient scale. In other words, the supply of works will be fewer than that of economically efficient. $^{155}$

In the case of an open collective, that is, a monopoly collective which opens its membership and treats all members equally in distributing any surplus, ${ }^{156}$ things will change. Under this situation, additional right holders will be attracted to join the collecting society because of the fact that the original members of the collective receive an equal portion of the surplus. ${ }^{157}$ As membership rises, the scale of the repertoire rises as well, leading to the increase of the license fee. The membership will continue to grow until the revenue per member equals the marginal cost of a song plus each member's aliquot share of the administrative costs. ${ }^{158}$ In this sense, the works produced will exceed the economically efficient level. However, no surplus will be generated for members. ${ }^{159}$

\subsubsection{THE POSITIVE EFFECT OF MONOPOLY}

As mentioned in the previous sections, the general idea behind the proliferation of collective management of copyright is that, because individual management of copyright is expensive and even impractical, collective management is the most effective and efficient way for licensing, collecting and distributing copyrights and royalties. As a consequence,

\footnotetext{
152 Besen, Kirby and Salop (N 11) 390.

${ }^{153}$ Handke and Towse (N 8) 942.

154 Besen, Kirby and Salop (N 11) 394.

155 Ibid.

${ }^{156}$ Id 396.

157 Ibid.

158 Id 397.

159 Ibid.
} 
society is better served by a single seller in this regard. ${ }^{160}$ Thus, the argument behind collective management of copyright is that the market for managing such rights is a natural monopoly. ${ }^{161}$ A natural monopoly forms when a single entity can supply a good or service to an entire market at a lower cost than could two or more entities. ${ }^{162}$ When a natural monopoly exists, it is believed that there are economies of scale in the monitoring, licensing, collecting and distributing of copyrights, which make the management of an aggregate of rights more efficient than the management of a single or few rights. ${ }^{163}$

Economies of scale are decreases in per unit cost resulting from increases in quantity produced or distributed. ${ }^{164}$ Some economists argue that once minimum optimal scale is achieved, long run average total cost is constant over a wide range of output, ${ }^{165}$ thus leading to increases of output. In mesuring scale economies, economists have developed various measurement techniques, namely product-specific ${ }^{166}$, plant-specific $^{167}$, and firm-specific ${ }^{168}$. In analyzing the operation of collecting societies, we will apply the firm-specific technique.

First of all, it is easily understandable that the per-work costs of monitoring usage and infringement and enfocing the rights tend to be lower as the number of works increases. ${ }^{169}$ When all related rights are managed by a single $\mathrm{CMO}$, the cost of such behavior is the lowest. The rationale of this is that the concentration of copyrighted works makes the costs that every right holder bears lower, this negative relevance reaches a peak when the extreme case that only one CMO managing all copyrighted works exists. It is noteworthy that when it comes to economies of scale, only the fixed costs rather than the variable costs are degressive. Although there involve considerable fixed costs that accrue during the establishing

${ }^{160}$ Katz (N 118) 543.

161 Ibid.

162 Mankiw (N 44) 314.

163 Katz (N 118) 553.

164 Laudati, LL 1980-1981, “Economies of Scale: Weighing Operating Efficiency When Enforcing Antitrust Law", Fordham Law Review, vol. 49, pp. 774.

165 Id 776.

166 Product-specific economies are associated with the volume of any single product made and sold. Ibid 779.

167 Plant-specific real economies are the decline of production and distribution unit costs as plant capacity and production increase. Ibid 780 .

168 Firm-specific real economies are the decline in production and distribution unit costs as firm size increases. Ibid.

169 Katz (N 118) 556. 
and maintaining process of collective management, these costs can be reduced on an average basis through the volume of produced transactions. ${ }^{170}$ Moreover, economies of scale can have a deterreing effect upon the grant of injuntive relief by the court. ${ }^{171}$ Note that when individual right holder seeking an injunctive relief from the court, it is true that this particular injuncion will only have a prohibitive effect upon the specific work of the owner rather than other copyrighted works. This means that the illegal user can continue to use other right holders' works without authorization. On the other hand, if the injunction is sought by a collecting society, the result will be that the unauthorized user will be prevented to use any of the works available in the collecting society's repertory in the future. ${ }^{172}$ This mechanism is considered socially efficient as it facilitates the enforcement of copyright.

\subsection{MEANS TO MITIGATE THE IMPACT OF MONOPOLY}

The analysis above shows that a monopoly collective will harm the copyright market from two perspectives. That is, by charging a higher price and by producing less intellectual works. Generally speaking, to mitigate the negative effect that a monopoly collecting society brings, two methods can be adopted: bilateral monopoly and regulation.

\subsubsection{BILATERAL MONOPOLY}

In our previous analysis we know that the monopoly collective sets an allor-nothing license fee. This means that potential users only by accepting the rate set by collective can be granted a license or otherwise they have to leave. By this ability that can deny the licensee access to its library the collecting society is able to receive its entire value of the license. ${ }^{173}$ Things may change under bilateral monopoly. A general definition of bilateral monopoly delievered by Druckman and Bonoma is that

"a situation where two parties are forced to deal exclusively with one another and to reach agreement in order to derive any profit from the interaction." 174

\footnotetext{
${ }^{170}$ Handke and Towse (N 8) 944.

${ }^{171}$ Katz (N 118) 557.

172 Ibid.

${ }^{173}$ Besen, Kirby and Salop (N 11) 398.
} 
When licensees gather in groups negotiate with collectives rather than individually, their bargaining power increases exponentially to the extent that a group of licensess can threaten to withhold the contract collectively. In effect, collective bargaining by potential users creates a situation in which neither side is able to dominate the other; and the outcome will approximate those expected in a competitive market. ${ }^{175}$

In his thought provoking article, Professor Richard Friedman proposes the "bargaining model" to analyze bilateral monopoly. Under this model, both parties in the transaction are able to bargain about both price and quantity of the contract. ${ }^{176} \mathrm{He}$ argues that the way that both parties make greater profits is by enlarging the total profit "pie" that they share, ${ }^{177}$ i.e., the number of transaction rather than the price of the transaction. ${ }^{178}$ The Pareto optimal quantity will be achieved at a point where the joint profit of the two parties equals the profit that they would make by selling the same amount of goods if they merged into a single monopolist. ${ }^{179}$ From game theory it is well known that the equilibrium solutions typically assigns shares of the market surplus to each negotiator on the basis of their relative bargaining powers. Bileral monopoly, then, is an effective way in which the market power of the monopolist can be eliminated. ${ }^{180}$

Bilateral monopoly has long been the case in the UK between the PRS (Performing Rights Society) and the BBC (British Broadcasting Corporation). ${ }^{181}$ It is reported that without the solidarity of the monopoly for composers through the PRS, the BBC would probably set a much lower fee and force the individual owners to accept. ${ }^{182}$ Also, the monopolistic power of the collecting society is substantially reduced as a result of the fact that many users negotiate with the collective through a trade association

\footnotetext{
${ }^{174}$ Druckman, D and Bonoma, TV 1976, “Determinants of Bargaining Behavior in a Bilateral Monopoly Situation II: Opponent's Concession Rate and Similarity", Behavioral Science, vol. 21, pp. 252. Also see Friedman, RD 1997, "Antitrust Analysis and Bilateral Monopoly", Journal of Reprints Antitrust Law \& Economics, vol. 27, pp. 839.

175 Sobel, LS 1983, "The Music Business and the Sherman Act: An Analysis of the "Economic Realities" of Blanket Licensing", Loyola L.A. Entertainment Law Journal, vol. 3, pp. 40.

176 Friedman (N 174) 845-46.

177 Id 846.

178 Ibid.

179 Ibid.

${ }^{180}$ Watt (N 57) 192.

${ }^{181}$ Handke and Towse (N 8) 944.

182 MacQueen, HL and Peacock, A 1995, “Implementing Performing Rights", Journal of Cultural Economics, vol. 19, pp. 166.
} 
or similar body. ${ }^{183}$ Other illustrations of bilateral monopoly involve radio and television stations, and hotels and motels organize into industry-wide associations.

\subsubsection{REGULATION OF NATURAL MONOPOLY}

Another way to deal with the problem of monopoly is by regulating the behavior of monopolistic collecting societies. This solution is particularly common in the case of natural monopoly. It is generally acknowledged that the regulatory control of natural monopoly occurs by: (1) limiting entry; (2) setting prices; (3) controlling profits; and (4) imposing a service obligation. ${ }^{184}$

As mentioned above, in most countries there are a limited number of collecting societies managing practically all categories of rights, where the conditions for the establishment of a new collective are reletively high. For example, in China the law has set various requirements for the establishment of collective organizations, which include: (1) no less than 50 obligees who promote the establishment of the organization for collective administration of copyright; (2) the scope of business of the organization for collective administration of copyright shall not be overlapped with that of another lawfully registered organization for collective administration of copyright; (3) the organization for collective administration of copyright may represent the benefits of relevant obligees throughout the country; and (4) the organization for collective administration of copyright has formulated a draft of its articles of association, a draft of royalty rates to be charged, and a draft of the measures for transferring royalties to the obligees. ${ }^{185}$ Such requirements basically prevent most of individuals from setting up new collecting societies. Additionally, there are also national laws (e.g., those of Switzerland and Hungary) that explicitly provide that only one organization may be authorized to manage the same right for the same category of rights owners. ${ }^{186}$

\footnotetext{
${ }^{183}$ Handke and Towse (N 8) 944.

${ }^{184}$ Tomain, J 2001-2002, "The Persistence of Natural Monopoly", 16 Nat. Resources \& Env't., pp. 243.

185 Art. 7, Regulation on the Collective Administration of Copyright (adopted at the 74th executive meeting of the State Council on December 22, 2004, and shall come into force on March 1, 2005).

${ }^{186}$ Ficsor (N 2) 136.
} 
What price should a copyright collective set for a license? This question is not as easy as it might at first appear. For one thing, finding the logical socially optimal price is almost impossible in the real life economies. For another, it is highly difficult to predict the preference of consumers whose varied and fast-changing interest in intellectual goods might divert from one type of works to another from time to time. Actually, Besen and Kirby's statement that 'One of the great frustrations in conducting the research for this report has been our inablity to obtain a precise answer to the question that we asked of many copyright collectives, "How are your tariffs determined?"187 delievers the difficulty of license pricing. In the extreme case whenever the bilateral bargaining rule has not been established, it is a reality that copyright collective set the price of license unilaterally according to the rules of thumb rather than precise information regarding the actual supply and demand situation of copyrighted works, or even the costs of marketing the repertoire. ${ }^{188}$ Given this, perhaps the most efficient means that the government can do to regulate license pricing is by offering users public subsidies with the goal of helping them organize together into groups and form stronger bargaining powers. In addition, governmental intervention of the fees set by collecting societies is not uncommon. ${ }^{189}$ Examples include the Performing Right Tribunal in the United Kingdom, the Federal Arbitral Commission in Switzerland, and the German Patent Office. ${ }^{190}$ These regulatory bodies in some jurisdictions would oversee the reasonableness of the fees set by local copyright collectives whereas in others they would directly set the license fee if the parties cannot reach an agreement. ${ }^{191}$ Some commentators suggest that, however, if the collecting societies themselves cannot determine the price of the license, it would hardly be any easier for the regulators to set this price. ${ }^{192}$

With regard to profit controlling, it is regulated by the majority of domestic laws that the collecting societies are operated under a not-for profit basis. After deduction of necessary management costs, the remaining royalties collected should all be distributed to copyright holders, no portion

\footnotetext{
${ }^{187}$ Besen and Kirby (N 97) 81.

188 Watt (N 57) 193.

189 Ibid.

190 Besen, Kirby and Salop (N 11) 405.

191 Ibid.

192 Handke and Towse (N 8) 944.
} 
of the remuneration collected by such organizations should be used forApurposes other than covering the actual costs of management and for the distribution fo the remaining amounts to the rights owners concerned without the permission of the rights owners. ${ }^{193}$

Other than covering actual costs and distribution of remuneration to individual rights owners, collective management organizations are also obliged to fulfill some cultural and social responsibilities. Cultural purposes mainly mean the use of certain amounts for the promotion of creativity (through prizes, competitions, fellowships, etc.), while social purposes usually involve the transfer of the money to health insurance or pension funds. ${ }^{194}$

As noted before, the most valuable product that a collecting society markets is a blanket license to its repertoire. By actively inflating the repertoire of the collecting societies with songs, the blanket license in itself increases its value. Some users, ${ }^{195}$ however, accuse such behavior of tying $^{196}$ - which if proven may be a per se violation of the antitrust laws since many songs available in the library are unwanted by the users. Such allegation is not uncommon as the users claim that the tying product is popular songs while the tied product is unpopular songs. This argument, however, fails upon examination because blanket license lacks the essential characteristics of a true tying arrangement. ${ }^{197}$ The reason for this is that the popular items are not used to market the unpopular ones. ${ }^{198}$ The royalties collected by collectives are distributed on the basis of use. In other words, the less popular song will receive less revenue and the song that is not used at all will earn no revenue. Consequently, collecting societies do not increase the sale of less popular goods by marketing blanket license. As a matter of fact, collectives nowadays would specialize as much

193 Ficsor (N 2) 149.

194 Id 149-50.

195 CBS v ASCAP, 400 F. Supp. 737, 745 (S.D.N.Y. 1975), rev'd, 562 F.2d 130 (2d Cir. 1977), rev'd sub nom. BMI v CBS, 441 U.S. 1 (1979).

196 According to Professor Maralee Buttery, tying involves three elements: two distinct items must be sold on terms that condition the sale of the first product (the tying product) on the sale of the second, inferior product (the tied product); the seller has sufficient market power for the tying product to restrain competition in the tied product market; a "not insubstantial" amount of commerce must be affected by the arrangement. See Buttery, M 1983, "Blanket Licensing: A Proposal for the Protection and Encouragement of Artistic Endeavor", Columbia Law Review, vol. 83, pp. 1269.

197 Buttery (N 196) 1270.

198 Ibid. 
as the set of users is specialized. ${ }^{199}$ For example, collecting societies will fine tune their repertoire to offer blanket license to their users relying on their specific requirements. ${ }^{200}$

\section{CONCLUSION}

Collective management of copyright provides an efficient means to cure the problem brought by the public goods characteristics of copyright. Under the arrangement of blanket license, users become much easier to get a use permit which involves all the materials they want to use. Free riding is thus eliminated to a large extent because potential infringers find that the costs of infringement will be higher than the costs of acquiring a license.

By exploiting economies of scale, collective management organizations are capable of pooling the high transaction costs among their members and uers. Hereby CMOs make licensing cheaper and further facilitate the markets for copyrights. This saving of costs can thus be channeled into foundation which assists the creation of more new works as well as the dissemination of culture.

In economic terms, the collecting society is likely to be a natural monopoly. How to regulate a natural monopoly effectively still remains questionable. Is leaving the collectives in tact and at the same time regulating their behaviors the most feasible way? If so, whether directly or indirectly regulation is more suitable? How much governmental intervention is enough? These questions are still left unanswered. Perhaps Professor Fabrice Rochelandet's empirical study which shows that copyright collectives that are strongly controled outperform those intermediarily and relatively weak controled ${ }^{201}$ may provide us with some insights.

\footnotetext{
199 Watt (N 57) 191.

200 That is to say some collecting societies will offer blanket licenses to pop music while others will offer blanket licenses to country music. Ibid.

201 Rochelandet, F 2003, "Are Copyright Collecting Societies Efficient Organizations? An Evaluation of Collective Administration of Copyright in Europe", in Gordon, WJ and Watt, R (eds.), The Economics of Copyright: Developments in Research and Analysis, Edward Elgar, pp. 192.
} 


\section{LIST OF REFERENCES}

Band, J and Butler, B 2013, "Some Cautionary Tales about Collective Licensing", Michigan State University College of Law International Law Review, vol. 21, pp. 687-728.

Barnes, D 2010-2011, “Congestible Intellectual Property and Impure Public Goods", Northwestern Journal of Technology E Intellectual Property, vol. 9, issue 8 , pp. 533-563.

Besen, S and Kirby, S “Compensating Creators of Intellectual Property: Collectives that Collect" RAND Corporation No. G-86102.

Besen, S, Kirby, S and Salop, S 1992, "An Economic Analysis of Copyright Collectives", Virginia Law Review, vol. 78, pp. 383.

Buttery, M 1983, “Blanket Licensing: A Proposal for the Protection and Encouragement of Artistic Endeavor", Columbia Law Review, vol. 83, pp. 1245-1278.

Carrier, M 2004-2005, “Cabining Intellectual Property Through A Property Paradigm", Duke Law Journal, vol. 54, pp. 1-145.

Cirace, J 1985-1986, “An Economic Analysis of Antitrust Law's Natural Monopoly Cases", West Virginia Law Review, vol. 88, pp. 677-728.

Coase, R 1937, “The Nature of the Firm”, Economica, vol. 4, pp. 386.

Coase, R 1960, “The Problem of Social Cost”, Journal of Law E Economics, vol. 3 , pp. 1.

Cooter, R and Ulen, T Law \& Economics, 5th Edition Pearson.

Demsetz, H 1970, “The Private Production of Public Goods”, Journal of Law E Economics, vol. 13, pp. 293-306.

Druckman, D and Bonoma, T 1976, “Determinants of Bargaining Behavior in a Bilateral Monopoly Situation II: Opponent's Concession Rate and Similarity", Behavioral Science, vol. 21, pp. 252. 
Ficsor, M 2002, "Collective Management of Copyright and Related Rights", WIPO Publication.

Friedman, R 1986, “Antitrust Analysis and Bilateral Monopoly”, Wisconsin Law Review, pp. 837-884.

Goldstein, P 1992, “Commentary on 'An Economic Analysis of Copyright Collectives'", Virginia Law Review, vol. 78, pp. 413-415.

Gordon, W 1991-1992, “Asymmetric Market Failure and Prisoner's Dilemma in Intellectual Property", University of Dayton Law Review, vol. 17, pp. 853-869.

Gordon, W 1982, “Fair Use as Market Failure: A Structural and Economic Analysis of the Betamax Case and its Predecessors", Columbia Law Review, vol. 82, pp. 1600-1657.

Gordon, W and Watt, R 2003, The Economics of Copyright: Developments in Research and Analysis, Edward Elgar.

Handke, C and Towse, R 2007, “Economics of Copyright Collecting Societies", International Review of Intellectual Property and Competition Law, vol. 38(8), pp. 937-957.

Hansen, G and Schmidt-Bischoffshausen, A 2007, "Economic Funtions of Collecting Societies - Collective Rights Management in the Light of Transaction Cost and Information Economics", 6 GRUR Int. 461.

Harrison, J and Theeuwes, J 2008, Law \& Economics, W. W. Norton \& Company, Inc.

Hollander, A 1984, “Market Structure and Performance in Intellectual Property: The Case of Copyright Collectives", International Journal of Industrial Organization, vol. 2, pp. 199-216.

Johnson, W 1992, “Commentray on 'An Economic Analysis of Copyright Collectives'", Virginia Law Review, vol. 78, pp. 417-419. 
Katz, A 2006, “The Potential Demise of Another Natural Monopoly: New Technologies and the Administration of Performing Rights", Journal of Competition Law \& Economics, vol. 2, pp. 245-284.

Katz, A 2005, "The Potential Demise of Another Natural Monopoly: Rethinking the Collective Administration of Performing Rights", Journal of Competition Law \& Economics, vol. 1, pp. 541-593.

Kay, J 1993, “The Economics of Intellectual Property Rights", International Review of Law and Economics, vol. 13, pp. 337-348.

Kennedy, M 1984, “Blanket Licensing of Music Performing Rights: Possible Solutions to the Copyright-Antitrust Conflict", Vanderbilt Law Review, vol. 37, pp. 183-216.

Kretschmer, M "Access and Reward in the Information Society: Regulating the Collective Management of Copyright", paper delivered at the 6th National Intellectual Property Workshop (Cambridge, 27 June 2005), and at the annual congress of the Society for Economic Research on Copyright Issues (Montreal, 7-8 July 2005).

Landes, W and Posner, R 1989, "An Economic Analysis of Copyright Law", Journal of Legal Studies, vol. 18, pp. 325-363.

Laudati, L 1980-1981, “Economies of Scale: Weighing Operating Efficiency When Enforcing Antitrust Law", Fordham Law Review, vol. 49, p. 771-801. Liu, J 2000-2001, “Owning Digital Copies: Copyright Law and the Incidents of Copy Ownership", William \& Mary Law Review, vol. 42, pp. 1245-1366.

Long, C 2004, "Information Costs in Patent and Copyright", Virginia Law Review, vol. 90, pp. 465-549.

Loren, L 2002-2003, "Untangling the Web of Music Copyrights", Case Western Reserve Law Review, vol. 53, pp. 673-722. 
Lunney, G 2007-2008, “Copyright's Price Discrimination Panacea”, Harvard Journal of Law \& Technology, vol. 21, pp. 387-456.

Lunney, G 2009, “Copyright, Private Copyring, and Discrete Public Goods”, Tulane Journal of Technology \& Intellectual Property, vol. 12, pp. 1-33.

MacQueen, H and Peacock, A 1995, “Implementing Performing Rights", Journal of Cultural Economics, vol. 19, pp. 157-175.

Mankiw, G 2007, Principles of Economics, Fourth Edition, Cengage Learning Asia Pte, Ltd.

Mankiw, G 2009, Principles of Economics, Fifth edition. Cengage Learning Asia Pte Ltd.

Masiyakurima, P 2006-2007, “The Effectiveness of Judicial Licensing in Copyright Law", Journal, Copyright Society of the U.S.A., vol. 54, p. 799828.

Merges, R 1996, "Contracting into Liability Rules: Intellectual Property Rights and Collective Rights Organizations", California Law Review, vol. 84, pp. 1293-1393.

Merges, R 1994, “Of Property Rules, Coase, and Intellectual Property”, Columbia Law Review, vol. 94, pp. 2655-2673.

Meyer, A 2005, “DRMS Do Not Replace Collecting Societies”, in Graber, CB, Govoni, C, Girsberger, M, and Nenova,M (eds.), “Digital Rights Management: The End of Collecting Societies?", Berne: Staempfli Publishers Ltd.

Posner, R 1968-1969, “Natural Monopoly and Its Regulation”, Stanford Law Review, vol. 21, pp. 548-643.

Posner, R 2004-2005, “Transaction Costs and Antitrust Concerns in the Licensing of Intellectual Property", John Marshall Review of Intellectual Property Law, vol. 4, pp. 325-335. 
Primeaux, W 1979, "Some Problems with Natural Monopoly", Antitrust Bulletin, vol. 24, pp. 63-85.

Sobel, L 1983, "The Music Business and the Sherman Act: An Analysis of the 'Economic Realities' of Blanket Licensing", Loyola Entertainment Law Journal, vol. 3, pp. 1-50.

Takeyama, L, Gordon, W, and Towse, R 2005, Developments in the Economics of Copyright: Research and Analysis, Edward Elgar.

Taylor, A 2007-2009, “Defeating Market Failure: Creating Successful Markets by Encouraging Market Creation by Individual Copyright Holders", Adelphia Law Journal, vol. 16, pp. 39-61.

Tournier, J and Joubert, C 1986, "Collective Administration and Competition Law", Copyright, vol. 22, pp. 96.

Towse, R 2002, Copyright in the Cultural Industries, Edward Elgar.

Tyerman, B 1970-1971, “The Economic Rationale for Copyright Protection for Published Books: A Reply to Professor Breyer", UCLA Law Review, vol. 18, pp. 1100-1125.

Wagner, P 2003, “Information Wants to be Free: Intellectual Property and the Mythologies of Control", Columbia Law Review, vol. 103, pp. 995-1034.

Watt, R 2010-2011, “Copyright and Contract Law: Economic Theory of Copyright Contracts", Journal of Intellectual Property Law, vol. 18, pp. 173-206.

Watt, R. 2000, Copyright and Economic Theory: Friends or Foes?, Edward Elgar Publishing, Inc.

Williamson, O 1981, “The Economics of Organization: The Transaction Cost Approach", The American Journal of Sociology, Vol. 87, No. 3, pp. 548-577.

Williamson, O 1979, "Transaction-cost Economics: The Governance of Contractual Relations", Journal of Law E Economics, vol. 22, p. 233-261. 